\title{
一酸化窒素（NO）による感染防御と 病態形成に関する研究
}

\author{
赤 池 孝 章
}

熊本大学医学部微生物学教室

于860-0811 熊本市本荘2-2-1

[受理 : 2001 年 8 月 1 日]

一酸化窒素（nitric oxide，NO）は，循環系・神経系の情報伝達にとゼまらず，感染・炎症・免疫 反応のメディエーターとして機能し，さらには免疫反応の調節，アポトーシスの制御，発癌など幅広 い生命現象にかかわっていることが明らかにされつつある。この様な多彩な活性は，NO そのものに よる直接的作用のみならず，パーオキシナイトライトなどの NO 由来の反応性窒素酸化物により間 接的に発現されることもわかってきた。興味あることに, NO は感染症においてほぼ普遍的に産生さ れ，生体内で抗菌活性を発揮するだけでなく病原体と宿主の相互作用を修飾する重要な役割を演じて いる。感染防御之病態形成における NO の多彩な生物活性の解明は，21世紀における感染病因論の 新たな展開の糸口となるかもしれない。

\section{1.はじめに}

1980年代後半，ガス状の非常に単純な無機ラ ジカル分子である一酸化窒素（NO）が，血管内 皮細胞より産生される血管平滑筋弛緩因子の本態 であることが明らかにされた（24）。との後，マ クロファージなどの感染防御のエフェクター細胞 からも, NO が産生され, 宿主の感染防御に関与 していることが報告された。さらにこれまで， NO は, 神経情報伝達の調節や, 炎症反応, 酸化 ストレス・細胞死の制御, 変異原性・発癌など様 々な生理機能や病態生理活性の発現に関与してい ることがわかっている（図 1）(9)。

この様な NO の生物活性の多面性は, NO その ものの活性に加えて, NO 由来の反応性窒素酸化

\section{Takaaki AKAIKE}

NO in Host Defense and Microbial Pathogenesis Department of Microbiology, Kumamoto University School of Medicine, Kumamoto 860-0811
物の作用によるものと考えられている。例えば， NO は生体内の主要な酸素ラジカルであるスー パーオキサイド $\left(\mathrm{O}_{2}^{-}\right)$と速やかに反応し, $\mathrm{NO}$ やスーパーオキサイドより反応性の高いパーオキ シナイトライト $\left(\mathrm{ONOO}^{-}\right)$を生じ, また, $\mathrm{NO}$ の酸化物である亜硝酸イオン $\left(\mathrm{NO}_{2}^{-}\right)$が過酸化 水素 $\left(\mathrm{H}_{2} \mathrm{O}_{2}\right)$ 依存的に好中球ミエロパーオキシ ダーゼなどにより酸化され，二酸化窒素 $\left(\mathrm{NO}_{2}\right)$ が生成することが明らかにされている。NOの活 性発現のニニークな点は, このような反応性窒素 酸化物が, NO の多彩な生理活性・病態生理活性 の影の立て役者として活躍しているといらことで ある（図 2 )。そこで本稿に拈いては，NO やそ れ由来の反応性窒素酸化物の多彩な機能に焦点を あてながら, 細菌・ウイルスなど様々な病原体に 対する感染防御と病態形成に和けるNO の役割 を論ずる。 
有害な作用

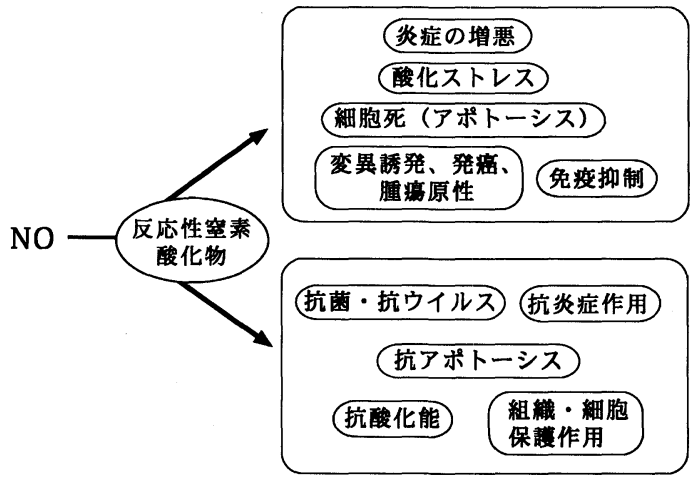

有益な作用

図 1.NO の病態生理活性の多様性。NO の多彩な機能 は, NO と酸素ラジカルや遷移金属イオン $(\mathrm{Fe}$, $\mathrm{Cu}$ )などとの反応を経て産生される各種反応性窒 素酸化物の多様な化学的・生物学的反応性にもと づき発現される。

\section{2. 感染病態における NO の産生誘導}

感染・炎症反応に括ける宿主応答に拈いて, 誘 導型 NO 合成酵素（iNOS）が注湆普遍的に誘導 され，過剩な NO 産生がもたらされる（図 3 ）。 これまでに iNOSの発現が認められている細胞種 としてはマクロファージ，心筋細胞，血管平滑筋 細胞, 肝細胞, 気管支上皮細胞, 消化管上皮細 胞，各種腫瘍細胞など多岐にわたっているが (21)，各種感染病態に扮いては，例えば，グラ ム陰性菌の外膜成分である内毒素（エンドトキシ ン; lipopolysaccharide, LPS) や, 炎症性サイト カインとして知られるインターロイキン $1 \beta$ (IL-1 $\beta)$, 腫瘍壊死因子（TNF- $\alpha)$ ，インターフ ェロン $\gamma($ IFN- $\gamma)$ などが iNOS の発現を誘導す ることが知られている $(21 ， 22 ， 36)$ 。また黄色 ブドウ球菌の外毒素である toxic shock syndrome toxin-1（TSST-1）やグラム陽性球菌の菌体表層 のリポタイコ酸もiNOS 誘導能を示すことが報告 されている $(17,51)$ 。これらはそれぞれ単独で は誘導活性は低いが，いくつかの組み合わせによ って相乗的な増加が観察される。一方，iNOS の 発現は細菌感染のみならずウイルス感染において もほぼ普遍的に誘導され, その発現は多くの場合
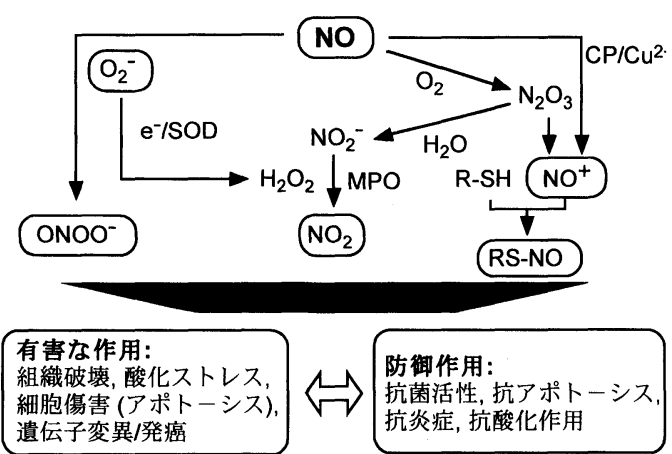

図 2.NO からの反応性窒素酸化物の生成メカニズム とそれらの生物活性。NOとスーパーオキサイド $\left(\mathrm{O}_{2}^{-}\right)$からパーオキシナイトライト $\left(\mathrm{ONOO}^{-}\right)$ が生じる。スーパーオキサイドから，スーパーオ キサイド不均化酵素（SOD）に触媒され，あるい は, 自然の不均化反応により生成する過酸化水素 $\left(\mathrm{H}_{2} \mathrm{O}_{2}\right)$ と, 好中球の myeloperoxidase (MPO) による亜硝酸イオン $\left(\mathrm{NO}_{2}^{-}\right)$の酸化反応により二 酸化窒素 $\left(\mathrm{NO}_{2}\right)$ が作られる。亜硝酸イオンは, NO が溶存酸素により水溶液中で酸化されて生ず る安定な窒素酸化物である。一方, NO は, 溶 存酸素により酸化され，ニトロソニウムイオン $\left(\mathrm{NO}^{+}\right)$となるが, この際, 生体内の $\mathrm{SH}$ 基 (R-SH) と付加反応が起こり，ニトロソチオール （RS-NO）が生成する。セルロプラスミン（CP） や銅イオンはこのニトロソチオール生成反応を触 媒し促進する。

IFN- $\gamma$ の産生誘導を介して間接的にもたらされる (図 3 )。

\section{NO の抗菌活性}

Hibbs らは，NO 発見の当初より，マクローフ アージに L-アルギニン依存的に発現される抗菌 活性が NO によるものであることを示唆してい た (23)。我々も，ラットの肺胞マクロファージ の非定型抗酸菌 (Mycobacterium avium complex, MAC) 感染系を用いて, MAC 感染に伴い過剩 に産生される $\mathrm{NO}$ が，細胞内の MAC に対して 増殖抑制作用を発現することを確認しているが， 興味あることに，MAC のある種の菌株は，NO 依存性の抗菌作用に対して抵抗性を示し，この様 な MAC 株に感染したマクロファージの機能が， 過剩に産生されるNO によりむしろ損なわれる ことを見出した（19）。最近では，NO が宿主免 疫応答に対して, 抑制作用を持つことが知られて 


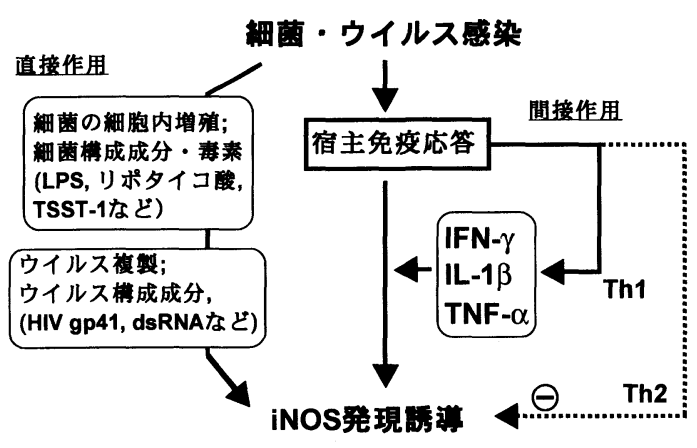

図 3. 細菌・ウイルス感染症に拈ける iNOS 発現誘導 メカニズム。iNOS は Th1 依存性である IFN- $\gamma$ の 誘導に伴い，間接的に誘導される。反対に，宿主 の Th2 応答は iNOS の発現に対して抑制的に作用 する。いくつかの病原体の構成成分や毒素は, iNOSを直接誘導する。また，抗酸菌などのマク 口ファージ内増殖 (感染) により, 直接, iNOS が誘導されることもある。

おりり, NO の免疫抑制作用については後ほど改め て紹介する。

一方, 生理的濃度の NO にははっきりした抗 菌作用が確認できない。実際我々は, NO に依存 した抗菌作用は，NO そのものといらょり，NO 由来の反応性の高い酸化物であるパーオキシナイ トライトや $\mathrm{NO}_{2}$ によりもたらされることを 1990 代前半より指摘してきた（27，29，49）。この様 な反応性窒素酸化物による殺菌効果は, グラム陽 性・陰性菌を問わず，さらに，カンジダなどの真 菌に対しても発揮される。また，我々は，NOに よる抗菌活性の発現メカニズムに関して, ヒト血 清中の主要なプロテアーゼインヒビターである $\alpha_{1}$-proteinase inhibitor $\left(\alpha_{1} \mathrm{PI}\right)$ が NO により効率 よく=トロソ化され, 強い抗菌活性を発揮するこ とを明らかにした $(32,33)$ 。 NO が, 酸素分子 や銅イオンにより酸化される過程で, NO の一電 子酸化体である二トロソニウムイオン $\left(\mathrm{NO}^{+}\right)$ が生じ，これが蛋白質やアミノ酸の $\mathrm{SH}$ 基をニト ロソ化すること, 寸なわち, SH 基と付加体を形 成することが知られている $(1,4,25)$ 。この様 な, $\mathrm{SH}$ 基-NO 付加体をニトロソチオールと呼 び, 以前より, ニトロソチオールが抗菌作用を有 することが報告されていたが，例觉ば，生体内の 主要なニトロソ化合物であるニトロソログルタチ
オン（GS-NO）やニトロソ化アルブミンなどの 抗菌活性に比較して, ニトロソ化 $\alpha_{1} \mathrm{PI}$ は, 黄色 ブドウ球菌, $\mathrm{A}$ 群レンサ球菌, 大腸菌, ネズミ チフス菌など幅広い細菌に対して，極めて強力な 増殖抑制作用を示す $(1,32,33)$ 。

さらに, NO やニトソロチオールは, 生体内で 強い抗アポトーシス活性を発揮して, 細胞死を制 御していることが明らかにされている（1，25， 38)。我々は, NO やニトソロチオールが, A 群 レンサ球菌の exotoxin Bによるアポトーシス発 現や，ネズミチフス菌に感染した宿主の細胞・組 織のアポトーシスを抑えることにより，これらの 細菌の組織侵襲を軽減し, 間接的に, 宿主の感染 防御活性を高めていることを示唆する知見を得て 扣り (論文投稿中)，NO とよる生体防御作用は 実に多彩である。

\section{4. 感染病態における NO の二面性}

以上述べてきた様に，iNOS は，主として炎症 性サイトカインや病原体由来の成分により発現誘 導されることから，NO は感染病態に扣いて非特 異的（初期）感染防御のエフェクター分子として の位置付けがなされてきた。しかし実際には，病 原微生物の種類や感染時の状況により抗菌因子と して作用したり，あるいはまったく逆に病原因子 として宿主に有害な作用をるたらすなど二面性を 持つことがわかってきた $(2,7,8,9,34)$ 。そ こで以下に, 様々な感染症に打けるNO の役割 について概説する。

\section{1) 細菌感染と NO}

細菌感染症に持ける iNOS の発現は, 前述した 様に, グラム陰性菌の LPS やグラム陽性菌のリ ポタイコ酸などの菌体成分による直接的な誘導あ るいは炎症性サイトカインの誘導を介した間接的 経路を介して誘導される。また，結核菌や非定型 抗酸菌などの細胞内寄生菌のマクロファージ内増 殖によってもマクロファージに iNOS が発現され 過剩な NO 生成がもたらされる（19）（図 3 ）。 NO は, 電子伝達系に括けるエネルギー代謝に必 要なへム化合物などの鉄を含む酵素や，核酸合成 に関与するリボヌクレオチドレダクターゼを不活 化することが明らかにされて招り, 感染局所に拉 いてマクロファージや好中球などの炎症細胞によ 
り生成されるNO は, 病原微生物のエネルギー 代謝および核酸合成を阻害することによって，感 染防御作用を発現することが示唆されている (35)。さらに, これら炎症細胞の NADPH 才キ シダーゼや炎症局所で誘導されるキサンチンオキ シダーゼから産生されるスーパーオキサイドは, NO と速やかに反応してNOよりも反応性の高い パーオキシナイトライトを生じる (43)。このパー オキシナイトライトは強力な oxidant であり, 強 い細胞傷害性を有し NO の抗菌活性に関与する (27)。

我々はマウスチフス症モデルに扮いてサルモネ ラ（ネズミサルモネラ菌; Salmonella serovar Typhimurium）感染肝組織に拉ける iNOS の発 現誘導ととれに伴った NO とスーパーオキサイ ドの過剩生成を確認した（46）。この際 INOS は, 肝内で形成される微小膿瘍内に集積した好中球を 中心とする炎症浸潤細胞に強く発現されて特り, パーオキシナイトライトなどの反応性窒素酸化物 生成のバイオマーカーであるニトロチロシンの免 疫染色を施すと, 微小膿瘍内に限局した濃染像が 認められる。このモデルに NOS 阻害剂を投与し た場合や，あるいは，iNOS 欠損マウスのサルモ ネラ感染に括いては, 肝に括ける微小膿瘍形成不 全が観察され, 細菌数の増加とともに敗血症へと 移行し致死率が上昇することもわかっている （46）（論文投稿中）（図 4)。一方で我々は, iNOS 欠損マウスに拈けるサルモネラ感染肝組織 に怙いては，広範な肝細胞のアポトーシスがもた らされることを見出している。このことは, 前述 した通り，NO が単なる抗菌物質として作用する のではなく，その強い抗アポトーシス活性を介し て, 細胞・臓器保護作用を発揮し, 感染宿主の感 染防御作用を間接的にサポートしていることを示 している。

また, 長崎大学熱帯医学研究所の大石らのグ ループは, 緑膿菌による気道感染モデルなどに拉 いても，NO が感染防御能を発揮することを確認 して扣り (42), サルモネラ感染モデルのみなら ず，多くの細菌感染症に括いてはNO は抗菌的 に作用すると考兄られる。

一方, Helicobacter pylori による胃感染系に特 いては, ヒトの感染でも, スナネズミ感染やマウ

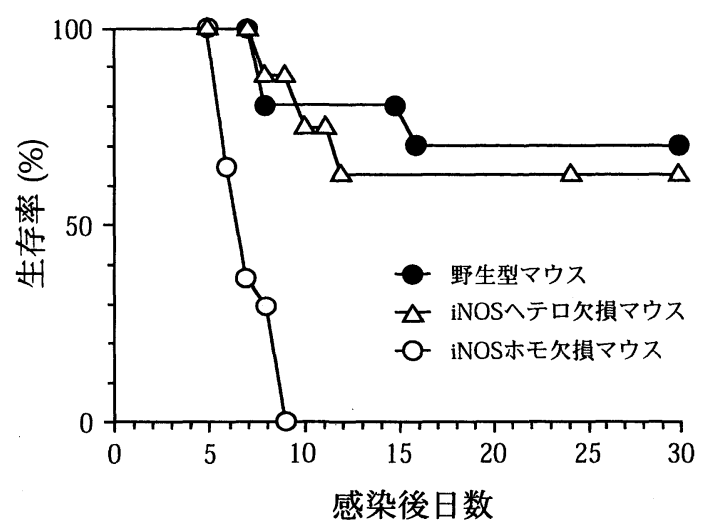

図 4.ネズミチフス菌感染による iNOS 欠損マウスの 生存率の時間経過。ネズミチフス菌 (Salmonella serovar Typhimurium LT2 株; $5 \times 10^{4} \mathrm{CFU/マウ}$ ス）を野生型マウス, 各種 iNOS 欠損マウスに腹 腔内投与した。

ス感染モデルに执いても, 感染胃粘膜局所におけ る iNOS の誘導とNO の過檋産生がもたらされる ものの, はっきりした NO 依存性の抗菌活性は 認められない。これは, H. pyloriが, パーオキ シナイトライトの消去システムを発現しているた め, NO の抗菌作用に耐性であるためであると推 察されている。例えば, 我々は, H. pylori の菌 体表層に発現されている強力なウレアーゼ活性を 介して産生される二酸化炭素 $\left(\mathrm{CO}_{2}\right)$ が，パーオ キシナイトライトと速やかに反応し，パーオキシ ナイトライトを菌体外で分解させることで, パー オキシナイトライトの菌体内へのアクセスを妨げ ていることを見出している（27）。また，H. pylori をはじめとして, いくつかの病原細菌は, パーオキシナイトライトに優れた消去活性を発揮 する peroxiredoxin を発現しているため, NO に よる抗菌活性に耐性を示しているといら指摘もな されている(16)。同様のメカニズムでNO に耐 性化している細菌としては，MACなどが知られ ているが，この様な NO 耐性菌による感染モデ ルに括いては, 感染に伴い過剰に産生される NO が, マクロファージなどの感染防御のェフェク ター細胞の機能障害や宿主の Th1 応答を低下さ せることにより, 感染防御免疫を抑制することも わかっている $(2,18,19)$ 。らに, H. pylori の慢性感染系に颃いては, NO 由来の反応性窒素 
酸化物により, 宿主細胞の塩基損傷を介して, 強 力な変異原性が発揮され, 胃癌の発生を誘発する 可能性も示唆されている $(2,9)$ 。従って, 当然 のことではあるが, 生体内に侵入した病原体の NO に対する感受性の有無が，宿主の感染応答に 特けるNOによる防御効果を決定する。

さらに, 過剩な NO 産生が, 宿主に不利に働 く場合として, 細菌性髄膜炎 $(11,45)$ や重症 細菌感染症である敗血症やエンドトキシンショッ クなどが挙げられる（50)。すなわち，iNOS に より過剒に産生される NO が，その強い血管弛 緩作用や細胞障害作用を介して，エンドトキシン ショックに括ける遷延性の低血圧症や acute respiratory distress syndrome (ARDS) 病態の増 悪の要因となることが明らかにされている。実際 我々は, NO 消去剤, PTIO (2-phenyl-4,4,5,5tetramethylimidazoline-1-oxyl-3-oxide）を開発 し，これが，ラットのエンドトキシンショックモ デルに対し, 著明な抗低血圧・抗ショック作用と 致死率の改善を示すことを報告している（6,

$13,28,29,50)$ 。

\section{2）ウイルス感染と NO}

ウイルス感染症に拈いても iNOS の誘導が認め られる $(2,5,7,8,10-12,20)$ 。細菌感染の 場合と同様に, ウイルス感染症に打いても, ウイ ルス構成蛋白や RNA による直接的な iNOS 誘導 が知られているが，多くの場合，IFN- $\gamma$ 等の炎症 性サイトカインによって間接的に誘導されるもの と考它らる(図 3 )。実際, 我々はマウスイン フルェンザウイルス感染モデルに执いてみられる 過唾な NO 産生が IFN- $\gamma$ ノックアウトマウスで は著明に抑制されることを確認している。NOの 抗ウイルス作用については議論のあるところで, 細菌感染とは対照的に, ウイルス種によりかなり 異なった報告が見られる。いくつかのウイルス， 特に DNA ウイルスでは NO が抗ウイルス活性を 持つことが指摘されて拉り，RNA ウイルスでは コクサッキーウイルスに対する抗ウイルス活性が 報告されている。しかし，その他のウイルスに対 するNO の抗ウイルス活性については不明の点 が多い。最近の報告では, オルソミクソウイル ス，パラミクソウイルス，マウスワクシニアウイ ルス, コロナウイルス, その他いくつかのウイル
スでは明らかな NO の抗ウイルス活性は認めら れないとされている $(2,7) 。$

我々はこれまで, ウイルス感染病態の执いて過 剰に産生される活性酸素・酸素ラジカルが宿主に 酸化ストレスを与え有害な影響を及ぼすことを示 してさた（3，30，37）。さらに我々は，マウス のインフルェンザウイルス执よびセンダイウイル ス肺炎モデルに执いてウイルス感染に対する感染 防御反応のひとつとして，iNOS が誘導され，局 所に過利な NO が産生されることを見出した $(5,10)$ 。このモデルに NOS 阻害剤を投与した り，iNOS 欠損マウスを用いて本モデルに括ける NO の役割を検討した結果, NO 産生が抑制され ることにより（あるいは, NO 産生が欠如するこ とにより), 肺炎像の改善とともに有意な生存率 の改善がもたらされ，このとさの肺内のウイルス 増殖は何ら变化を受けなかった。野生型マウスに 認められる浸潤マクロファージなどの炎症細胞や 肺胞内滲出液などのニトロチロシンの免疫染色は iNOS 欠損マウスでは医とんど認められないこと から, 本病態では NO は生体内で有効な抗ウイ ルス作用を発揮することなく，パーオキシナイト ライトなどの反応性窒素酸化物に変換されること により酸化ストレスののメディェータとして機能 し, 細胞傷害や組織障害をもたらすことが示唆さ れた $(31 ， 39 ， 41 ， 43 ， 44)$ 。また我々は最近, パーオキシナイトライトが，これまで知られてい なかった大変ュニークな蛋白質の翻訳後修飾を介 し, matrix metalloproteinase (MMP) を活性 化し，MMP 活性に依存した血管透過性え進と細 胞外マトリックスの分解をもたらすことにより， 感染・炎症病巣の組織破壊を促進することを明ら かにした (40，48)。同様の組織障害メカニズム がヘルペス脳炎モデルや肺炎モデルなど他のウイ ルス感染症でも認められて沏り，NO 依存性の組 織障害はウイルス感染症の病態発現において普遍 的なものである可能性が考えられる $(2,7) 。$

\section{3）NOによる病原体遺伝子の変異促進作用}

インフルェンザウイルスやヒト免疫不全ウイル ス (human immunodeficiency virus, HIV) など の RNA ウイルスは，その遺伝子複製の不正確さ により, 一回の複製でヌクレチド残基あたり $10^{-5} \sim 10^{-3}$ といら頻度で変異し, 極めて高度な 
遺伝的多様性をもつ集団，quasispecies として存 在し，様々な環境中のストレスにより淘汰されな がら分子進化を繰り返していると考えられている (2)。例壳ば，インフルェンザウイルスや HIV の, 薬剤耐性化, 中和抗体からのエスケープなど の現象などは, 効果的な抗ウイルス薬やワクチン の開発を困難にしており, 各種ウイルスの感染症 対策に㧤いて深刻な問題となっている。遺伝子の 多様性は，H. pylori などに执いても知られてお り, この様な, 遺伝学的多様性に基づいた病原体 の速やかな進化の分子メカニズムの解明は, ウイ ルスのみならず細菌感染対策に括いても重要な課 題である。

興味あることに, NO やパーオキシナイトライ トによる酸化ストレスが，宿主はもちろんこと， 局所で増殖を繰り返すウイルス側にも加えられ, ウイルスに変異原性をもたらし，その分子進化に 関わることがわかってきた。例えば，Beck ら は，コクサッキーウイルスの心筋炎モデルを用い て，酸化ストレスがコクサッキーウイルス弱毒株 の遺伝子にいくつかの点変異を誘発し, ウイルス が強毒株に変化することによりウイルスの病原性 が増強し, 致死的な心筋炎がもたらされることを 明らかにした（14，15）。また，ウイルス以外で は, 以前よりマクロファージから産生される活性 酸素が，通性細胞内寄生菌であるネズミチフス菌 に対して変異原性を発現することが知られている (47)。

一方我々は，酸化ストレスとウイルスの分子進

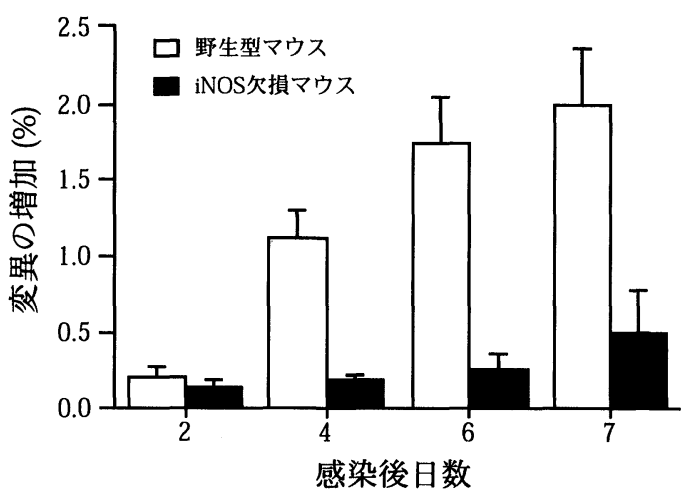

図 5. ウイルス肺炎に打けるNO 依存的ウイルス変異 促進。iNOS 欠損マウス技よび野生型マウスに GFP-SeV を経鼻噴霧感染させ，肺内で増殖したウ イルスの変異率を経時的に測定した。

化の関わりについて, 特に NO やパーオキシナ イトライトによるウイルスの変異促進作用に焦点 をあて解析を試みた（5）。具体的には, green fluorescent protein (GFP) 遺伝子を組み込んだ 組み変えセンダイウイルス (GFP-SeV) を, in vitro の系でパーオキシナイトライトにより処理 したり, iNOS 欠損マウスに感染させることで, GFP-SeV の GFP 遺伝子の変異率を解析した。 その結果, パーオキシナイトライトがウイルス遺 伝子に対して強い変異原性を発揮すること，ま た, NO の過剩生成がもたらされない iNOS 久損 マウスの肺炎病巣においては, 野生型マウスに比 較して GFP-SeV の変異率が有意に低いことがわ

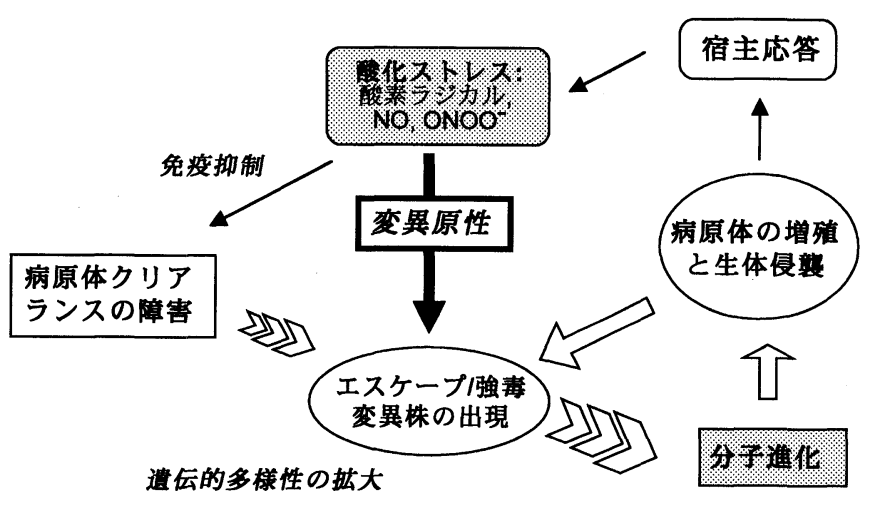

図 6. NO の病原体ゲノム変異と分子進化への関与。 
かった（図 5 )。さらに，この様な過㮃な NO 産 生に依存したウイルス変異率の上昇は, iNOS 遺 伝子をトランスフェクトし, iNOS を強制的に発 現した細胞の感染系に扣いて子確認された。これ らの知見は, 感染病態のメディエーターとして産 生されるパーオキシナイトライトをはじめとする $\mathrm{NO}$ 由来の窒素酸化物が, 宿主のみならず病原体 に対しても酸化ストレスをもたらし，病原体ゲ， ムの変異を促していることを示しておうう,さらに このことがウイルスゲノムの多様性を拡大させ, その分子進化を促進させるドライビングフォース となる可能性を示唆している（図 6 )。

\section{5.おわりに}

感染病態の本質は病原体と宿主の間で繰り広げ られるダイナミックな相互作用である。近年, 多 くの感染症の病態が，コッホ・北里らにより提唱 された画一的な感染病因論では，十分に理解でき ないことが指摘されはじめている。今後, 多彩な 生体機能を発揮する NOなどのフリーラジカル や反応性窒素酸化物の作用機構の分子基盤を明ら かにすることにより，感染病因論に打ける新たな パラダイムシフトが展開することが期待される。

\section{謝辞}

この度の小林六造記念賞受賞の応募にあたりご 推鹰の労を賜りました神谷 茂教授（杏林大学医 学部微生物学教室), および, 受賞の対象となり ました研究を遂行する機会を頂きました前田 浩 教授（能本大学医学部微生物学教室）に心より㧤 礼申し上げます。また，本研究遂行にあたり，貴 重なご助言とご指導を頂きました永井美之名古屋 大学名誉教授 (富山県衛生研究所長), ならびに, 発表論文に共著者として加わって頂きました多く の共同研究者の皆様と熊本大学医学部微生物学教 室の宮本洋一博士, 澤 智裕博士をはじめ, 大学 院生諸氏に深謝いたします。

\section{文献}

1) Akaike, T. (2000): Mechanisms of biological $S$ nitrosation and its measurement. Free Radic. Res. 33, 461-469.

2) Akaike, T. (2001): Role of free radicals in viral pathogenesis and mutation. Rev. Med. Virol. 11, 87-101.

3) Akaike, T., Ando, M., Oda, T., Doi, T., Ijiri, S., Araki, S., Maeda, H. (1990): Dependence on $\mathrm{O}_{2}{ }^{-}$ generation by xanthine oxidase of pathogenesis of influenza virus infection in mice. J. Clin. Invest. 85, 739-745.

4) Akaike, T., Inoue, K., Okamoto, T., Nishino, H., Otagiri, M., Fujii, S., Maeda, H. (1997): Nanomolar quantification and identification of various nitrosothiols by high performance liquid chromatography coupled with flow reactors of metals and Griess reagent. J. Biochem. 122, 459-466.

5) Akaike, T., Fujii, S., Kato, A., Yoshitake, J., Miyamoto, Y., Sawa, T., Okamoto, S., Suga, M., Asakawa, M., Nagai, Y., Maeda, H. (2000): Viral mutation accelerated by nitric oxide production during infection in vivo. FASEB J. 14, 1447-1454.

6) Akaike, T., Maeda, H. (1996): Quantitation of nitric oxide using 2-phenyl-4,4,5,5-tetramethylimidazoline-1-oxyl 3-oxide (PTIO). Methods Enzymol. 268, 211-221.

7) Akaike, T., Maeda, H. (2000): Nitric oxide and virus infection. Immunology 101, 300-308, 2000.

8) Akaike, T., Maeda, H. (1999): Nitric oxide in influenza. p. 397-415, Fang, F.C. (ed), In Nitric Oxide and Infection, New York, Kluwer Academic/Plenum Publishing Co.

9) Akaike, T., Maeda, H. (2000): Pahophysiological Effects of High-Output Production of Nitric Oxide. p. 733-745, In Ignarro, L.J. (ed), Nitric Oxide: Biology and Pathobiology, San Diego, Academic Press.

10) Akaike, T., Noguchi, Y., Ijiri, S., Setoguchi, K., Suga, M., Zheng, Y.M., Dietzschold, B., Maeda, H. (1996): Pathogenesis of influenza virus-induced pneumonia: involvement of both nitric oxide and oxygen radicals. Proc. Natl. Acad. Sci. U.S.A. 93, 2448-2453.

11) Akaike, T., Suga, M., Maeda, H. (1998): Free radicals in viral pathogenesis: molecular mechanisms involving superoxide and NO. Proc. Soc. Exp. Biol. Med. 217, 64-73.

12) Akaike, T., Weihe, E., Schaefer, M., Fu, Z.F., Zheng, Y.M., Voge, W., Schmidt, H., Koprowski, H., Dietzschold, B. (1995): Effect of neurotropic virus infection on neuronal and inducible nitric oxide synthase activity in rat brain. J. Neurovirol. 1, 118-125. 
13) Akaike, T., Yoshida, M., Miyamoto, Y., Sato, K., Kohno, M., Sasamoto, K., Miyazaki, K., Ueda, S., Maeda, H. (1993): Antagonistic action of imidazolineoxyl $N$-oxides against endothelium-derived relaxing factor/NO through a radical reaction. Biochemistry 32, 827-832.

14) Beck, M.A., Esworthy, R.S., Ho, Y.S., Chu, F.F. (1998): Glutathione peroxidase protects mice from viral-induced myocarditis. FASEB J. 12, 1143-1149.

15) Beck, M.A., Beck, M.A., Shi, Q., Morris, V.C., Levander, O.A. (1995): Rapid genomic evolution of a non-virulent coxsackievirus B3 in seleniumdeficient mice results in selection of identical virulent isolates. Nat. Med. 1, 433-436.

16) Bryk, R., Griffin, P., Nathan, C. (2000): Peroxynitrite reductase activity of bacterial peroxiredoxins. Nature 407, 211-215.

17) De Kimpe, S.J., Kengatharan, M., Thiemermann, C., Vane, J.R. (1995): The cell wall components peptidoglycan and lipoteichoic acid from Staphylococcus aureus act in synergy to cause shock and multiple organ failure. Proc. Natl. Acad. Sci. U.S.A. 92, 10359-10363.

18) Doherty, T.M., Sher, A. (1997): Defects in cellmediated immunity affect chronic, but not innate, resistance of mice to Mycobacterium avium infection. J. Immunol. 158, 4822-4831.

19) Doi, T., Ando, M., Akaike, T., Suga, M., Sato, K., Maeda, H. (1993): Resistance to nitric oxide in Mycobacterium avium complex and its implication in pathogenesis. Infect. Immun. 61, 1980-1989.

20) Fujii, S., Akaike, T., Maeda, H. (1999): Role of nitric oxide in pathogenesis of herpes simplex virus encephalitis in rats. Virology 256, 203-212.

21）藤井重元, 赤池孝章, 前田 浩 (1996): NO 合成 酵素の発現調節機構と NO の機能. 呼吸 $\mathbf{1 5}$, 151-158.

22) Fujisawa, H., Ogura, T., Hokari, A., Weisz, A., Yamashita, J., Esumi, H. (1995): Inducible nitric oxide synthase in a human glioblastoma cell line. J. Neurochem. 64, 85-91.

23) Hibbs, J.B. Jr., Taintor, R.R., Vavrin, Z. (1987): Macrophage cytotoxicity: role for L-arginine deiminase and imino nitrogen oxidation to nitrite. Science 235, 473-476.

24) Ignarro, L.J. (2000): Introduction and overview. p. 3-19, In Ignarro, L.J. (ed), Nitric Oxide: Biology and Pathobiology, San Diego, Academic Press.

25) Ikebe, N., Akaike, T., Miyamoto, Y., Hayashida,
K., Yoshitake, J., Ogawa, M., Maeda, H. (2000): Protective effect of $S$-nitrosylated $\alpha_{1}$-protease inhibitor on hepatic ischemia-reperfusion injury. J. Pharmacol. Exp. Ther. 295, 904-911.

26) Inoue, K., Akaike, T., Miyamoto, Y., Okamoto, T., Sawa, T., Otagiri, M., Suzuki, S., Yoshimura, T., Maeda, H. (1999): Nitrosothiol formation catalyzed by ceruloplasmin. Implication for cytoprotective mechanism in vivo. J. Biol. Chem. 274, 27069-27075.

27) Kuwahara, H., Miyamoto, Y., Akaike, T., Kubota, T., Sawa, T., Okamoto, S., Maeda, H. (2000): Helicobacter pylori urease suppresses bactericidal activity of peroxynitrite via carbon dioxide production. Infect. Immun. 68, 4378-4383.

28) Maeda, H., Akaike, T., Yoshida, M., Suga, M. (1994): Multiple functions of nitric oxide in pathophysiology and microbiology: analysis by a new nitric oxide scavenger. J. Leukoc. Biol. 56, 588-592.

29) Maeda, H., Akaike, T., Yoshida, M., Sato, K., Noguchi, Y. (1995): A new nitric oxide scavenger, imidazolineoxyl $N$-oxide derivative, and its effects in pathophysiology and microbiology. Curr. Top. Microbiol. Immunol. 196, 37-50.

30) Maeda, H., Akaike, T. (1991): Oxygen free radicals as pathogenic molecules in viral diseases. Proc. Soc. Exp. Biol. Med. 198, 721-727.

31) Maeda, H., Okamoto, T., Akaike, T. (1998): Human matrix metalloprotease activation by insults of bacterial infection involving proteases and free radicals. Biol. Chem. 379, 193-200.

32) Miyamoto, Y., Akaike, T., Alam, M.S., Inoue, K., Hamamoto, T., Ikebe, N., Yoshitake, J., Okamoto, T., Maeda, H. (2000): Novel functions of human $\alpha$ 1-protease inhibitor after $S$-nitrosylation: inhibition of cysteine protease and antibacterial activity. Biochem. Biophys. Res. Commun. 267, 918-923.

33) Miyamoto, Y., Akaike, T., Maeda, H. (2000): Snitrosylated human $\alpha_{1}$-protease inhibitor. Biochim. Biophys. Acta. 1477, 90-97.

34) Nathan, C. (1997): Inducible nitric oxid synthase: what difference does it make? J. Clin. Invest. 100, 2417-2423.

35) Nathan, C.F., Hibbs J.B. Jr. (1991): Role of nitric oxide synthesis in macrophage antimicrobial activity. Curr. Opin. Immunol., 3, 65-70.

36) Nussler, A.K., Billiar, T.R. (1993): Inflammation, immunoregulation, and inducible nitric oxide synthase. J. Leukoc. Biol. 54, 171-178. 
37) Oda, T., Akaike, T., Hamamoto, T., Suzuki, F., Hirano, T., Maeda, H. (1989): Oxygen radicals in influenza-induced pathogenesis and treatment with pyran polymer-conjugated SOD. Science 244, 974-976.

38) Ogura, T., Tatemichi, M., Esumi, H. (1997): Nitric oxide inhibits CPP32-like activity under redox regulation. Biochem. Biophys. Res. Commun. 236, 365-369.

39) Okamoto, T., Akaike, T., Nagano, T., Miyajima, S., Suga, M., Ando, M., Ichimori, K., Maeda, H. (1997): Activation of human neutrophil procollagenase by nitrogen dioxide and peroxynitrite: a novel mechanism for procollagenase activation involving nitric oxide. Arch Biochem Biophys. 342, 261-274.

40) Okamoto, T., Akaike, T., Sawa, T., Miyamoto, Y., van der Vliet, A., Maeda, H. (2001): Activation of matrix metalloproteinases by peroxynitrite-induced protein $S$-glutathiolation via disulfide $S$ oxide formation. J. Biol. Chem. (in press).

41) Sato, K., Suga, M., Akaike, T., Fujii, S., Muranaka, H., Doi, T., Maeda, H., Ando, M. (1998): Therapeutic effect of erythromycin on influenza virus-induced lung injury in mice. Am. J. Respir. Crit. Care Med. 157, 853-857.

42) Satoh, S., Oishi, K., Iwagaki, A., Senba, M., Akaike, T., Akiyama, M., Mukaida, N., Matsushima, K., Nagatake, T. (2001): Dexamethasone impairs pulmonary defense against Pseudomonas aeruginosa through suppressing iNOS gene expression and peroxynitrite production in mice. Clin. Exp. Immunol. (in press).

43) Sawa, T., Akaike, T., Maeda, H. (2000): Tyrosine nitration by peroxynitrite formed from nitric oxide and superoxide generated by xanthine oxidase. J. Biol. Chem. 275, 32467-32474.

44) Sugiura, H., Ichinose, M., Oyake, T., Mashito, Y., Ohuchi, Y., Endoh, N., Miura, M., Yamagata, S., Koarai, A., Akaike, T., Maeda, H., Shirato, K. (1999): Role of peroxynitrite in airway microvascu- lar hyperpermeability during late allergic phase in guinea pigs. Am. J. Respir. Crit. Care Med. 160, 663-671.

45) Suzuki, Y., Fujii, S., Tominaga, T., Yoshimoto, T., Fujii, S., Akaike, T., Maeda, H., Yoshimura, T. (1999): Direct evidence of in vivo nitric oxide production and inducible nitric oxide synthase mRNA expression in the brain of living rat during experimental meningitis. J. Cereb. Blood Flow Metab. 19, 1175-1178.

46) Umezawa, K., Akaike, T., Fujii, S., Suga, M., Setoguchi, K., Ozawa, A., Maeda, H. (1997): Induction of nitric oxide synthesis and xanthine oxidase and their roles in the antimicrobial mechanism against Salmonella typhimurium infection in mice. Infect. Immun. 65, 29322940.

47) Weitzman, S.A., Stossel, T.P. (1981): Mutation caused by human phagocytes. Science 212, 546-547.

48) Wu, J., Akaike, T., Hayashida, K., Okamoto, T., Okuyama, A., Maeda, H. (2001): Enhanced vascular permeability in solid tumor involving peroxynitrite and matrix metalloproteinases. Jpn. J. Cancer Res. 92, 439-451.

49) Yoshida, K., Akaike, T, Doi, T., Sato, K., Ijiri, S., Suga, M., Ando, M., Maeda, H. (1993): Pronounced enhancement of NO-dependent antimicrobial action by an NO-oxidizing agent, imidazolineoxyl $N$-oxide. Infect. Immun. 61, 3552-3555.

50) Yoshida, M., Akaike, T., Wada, Y., Sato, K., Ikeda, K., Ueda, S., Maeda, H. (1994): Therapeutic effects of imidazolineoxyl $N$-oxide against endotoxin shock through its direct nitric oxidescavenging activity. Biochem. Biophys. Res. Commun. 202, 923-930.

51) Zembowicz, A., Vane, J.R. (1992): Induction of nitric oxide synthase activity by toxic shock syndrome toxin 1 in a macrophage-monocyte cell line. Proc. Natl. Acad. Sci. U.S.A. 89, 2051-2055. 